\title{
PENGARUH PENGGUNAAN MODEL PEMBELAJARAN SQ4R DIPERBANTU TALKING STICK TERHADAP HASIL BELAJAR SISWA KELAS VIII A MTs ANNUR KOTA SORONG
}

\author{
Riswandi Rakka, Jaharudin, Ratna Prabawati
}

Prodi Biologi Unimuda Sorong

riswandi007rakka0072@gmail.com

\begin{abstract}
ABSTRAK
Penelitian ini bertujuan untuk mengetahui: Pengaruh Penggunaan Model Pembelajaran SQ4R diperbantu dengan Talking Stick terhadap Hasil Belajar Siswa VIII-A MTs Annur Kota Sorong. Penelitian ini merupakan quasi experiment. Desain eksperimen menggunakan model One Group Pretest-Posttest. Penelitian ini dilaksanakan di MTs Annur Kota Sorong dengan populasi seluruh siswa kelas VIII. Teknik pengambilan sampel menggunakan purposive sampling. Teknik pengambilan sampel menggunakan purposive sampling. Anggota sample sebanyak 18 siswa, yaitu kelas experimen sebanyak 18 siswa. Instrumen penelitian yang digunakan untuk mengambil data adalah hasil pretest dan posttest Analisis data terdiri atas uji normalitas dan uji t. Hasil penelitian menunjukkan bahwa pengaruh penerapan model pembelajaran SQ4R diperbantu dengan Talking Stick dapat meningkatkan hasil belajar siswa. Berdasarkan hasil penilaian pretest sebelum penerapan mode pembelajaran SQ4R dapat diketahui bahwa nilai tes dari 18 siswa yang mendapatkan nilai KKM yakni > 73 hanya 9 siswa atau sebesar $50 \%$, sedangkan ada 9 atau 50\% siswa yang nilainya dibawah KKM dengan nilai rata-rata hasil penilaian posttest $=71,8$, sedangkan berdasarkan hasil penilaian posttets diketahui bahwa siswa yang sudah memenuhi KKM yaitu $>73$ terdapat 18 siswa (100\%).
\end{abstract}

Kata kunci : SQ4R, Talking Stick, Hasil Belajar

ABSTRACT
This study aims to determine: The Effect of Using Learning Models The SQ4R was assisted by a Talking Stick of VIII-A MTs Annur students, Sorong City. This research is a quasi experiment. The experimental design uses the One Group Pretest-Posttest model. This research was conducted in MTs Annur Sorong City with a population of all VIII grade students. The sampling technique uses purposive sampling. Sample members were 18 students, namely the experimental class of 18 students. The research instrument used to retrieve data was the results of the pretest and posttest. Data analysis consisted of a normality test and a t test. The results showed that the effect of applying the SQ4R learning model assisted with a Talking Stick can improve student learning outcomes in biology subjects in the structure and function of plant organs. Based on the results of the pretest assessment prior to the application of the SQ4R learning mode it can be seen that the test scores of 18 students who received the KKM score of $\geq 73$ were only 9 students or 50\%, while there were 9 or $50 \%$ of students whose grades were below the KKM with the average value of the assessment results posttest $=71.8$, while based on the results of the posttets assessment it is known that students who have met the KKM $\geq 73$ there are 18 students (100\%).

Keywords: SQ4R, Talking Stick, Learning Outcomes

\section{Pendahuluan}

Menurut Permendikbud No. 103 Tahun 2014, pembelajaran adalah proses interaksi antarpeserta didik dan antara peserta didik dengan pendidik dan sumber belajar pada suatu lingkungan belajar (Permendikbud No. 103 Tahun 2014 Pasal 1 bagian ke-1). Pembelajaran dilaksanakan berbasis aktivitas dengan karakteristik interaktif dan inspiratif menyenangkan, menantang, dan memotivasi peserta didik untuk berpartisipasi aktif, kontekstual dan kolaboratif, memberikan ruang yang cukup bagi prakarsa, kreativitas, dan kemandirian peserta didik, juga sesuai dengan bakat, minat, kemampuan, dan perkembangan fisik serta psikologis peserta didik. Pembelajaran menggunakan pendekatan, strategi, model, dan metode yang mengacu pada karakteristik karakteristik tersebut.

Guru sebagai penyelenggara dan pengelola kegiatan pembelajaran, dituntut untuk lebih kreatif dan inovatif dalam mengatur kegiatan pembelajaran agar tercipta pembelajaran yang ideal. Pembelajaran ideal merupakan pembelajaran yang mampu membantu siswa untuk mencapai kompetensi yang diharapkan. Pembelajaran sains, khususnya biologi yang di dalamnya banyak termuat kegiatan eksplorasi dan konstruktivis, pada dasarnya mampu untuk meningkatkan kompetensi siswa. Salah satu kompetensi yang diharapkan dimiliki oleh siswa selama menjalankan pembelajaran biologi ialah hasil belajar kognitif. Untuk memperoleh hasil pembelajaran yang optimal, seorang guru dituntut memiliki sejumlah kemampuan dalam membuat persiapan pembelajaran (Rustaman, 2005).

Berdasarkan pengalaman pada program Praktik Pengalaman Lapangan (PPL) pada mata pelajaran Biologi, khususnya materi struktur dan fungsi organ pada tumbuhan dan hasil wawancara secara tidak terstruktur memperlihatkan bahwa hasil belajar siswa rendah dengan rata-rata 68 masih dibawah KKM dengan nilai tertinggi 80 dan nilai terendah 50. Selain 
itu dibuktikan pula hasil semester sebelum diremidial dengan nilai siswa masih dibawah KKM yang telah ditentukan oleh sekolah dengan nilai 73. Berdsarkan latar belakang masalah diatas maka peneliti tertarik melakukan judul penelitian: Pengaruh Penggunaan Model Pembelajaran SQ4R diperbantu dengan Talking Stick terhadap Hasil Belajar Siswa VIII-A MTs Annur Kota Sorong.

\section{Metode Penelitian}

Penelitian yang akan dilakukan merupakan jenis penelitian Quasi Eksperiment. Quasi Eksperiment merupakan metode eksperimen yang mengikuti prosedur dan memenuhi syarat eksperimen seperti kelompok kontrol, pemberian perlakuan, serta pengujian hasil. Namun, dalam pengontrolan variabel hanya dilakukan terhadap satu variabel yang dipandang paling dominan (Sukmadinata, 2008). Desain penelitian yang digunakan dalam penelitian ini yaitu One Group Pretest-Posttest. Meskipun tidak ada variabel kontrol atau kelas pembanding, hasil perlakuan dapat diketahui lebih akurat karena dapat membandingkan dengan keadaan sebelum diberi perlakuan (Sugiyono, 2016)

Sampel pada penelitian ini tidak menggunakan seluruh siswa kelas VIII, tetapi hanya menggunakan siswa di kelas VIII A . Dalam hal ini sampel yang digunakan harus representatif (mewakili populasi), sehingga harus dilakukan pengambilan sampel yang benar. Teknik sampling yang digunakan dalam penelitian ini adalah purposive sampling karena pengambilan sampel anggota populasi dilakukan melalui pertimbangan tertentu yaitu dengan mengambi satu kelas dari populasi yang memenuhi syarat. Jadi sampel pada penelitian ini siswa kelas VIII A MTs Annur Kota Sorong dengan jumlah sebanyak 18 siswa.
Analisis dan pengolahan data merupakan hal yang penting dalam susatu penelitian, dengan pengolahan data, data akan lebih berarti dan bermakna dalam pemecahan masalah. Adapun langkah langkahnya sebagi berikut.

\section{Uji Normalitas}

Uji normalitas digunakan untuk mengetahui apakah data yang dianalisis berdistribusi normal atau tidak. Jika data tidak berdistribusi normal maka uji $\mathrm{T}$ tidak dapat dilanjutkan. Suatu distribusi diakatakan normal jika taraf signifikannya $>0,005$, sedangkan jika signifikannya $<0,005$ maka distribusinya dikatakan tidak normal. Untuk menguji normalitas digunakan uji Test of Normality.

\section{Uji Hipotesis}

Uji hipotesis ini bertujuan untuk mengetahui pengaruh hasil belajar Biologi struktur dan fungsi organ di kelas eksperimen. Dalam uji hipotesis ini menggunakan Uji Paired Sample Test. Hipotesis yang digunakan dalam uji anova adalah sebagai berikut:

HO : Tidak ada pengaruh nilai rata rata hasil belajar antara siswa yang diberikan pembelajaran SQ4R dengan Talking Stick.

Ha: Ada pengaruh nilai rata rata hasil belajar antara siswa yang diberikan pembelajaran SQ4R dengan Talking Stick.

Uji Paired Sample Test analisis menggunakan program SPSS 20 dengan hipotesis seperti diatas, dengan kriteria diterima Ha jika Sig. (2tailed) kurang dari 0,05.

\section{Hasil dan Pembahasan}

Berdasarkan penelitian yang dilakukan di MTs Annur pada peserta didik kelas VIII-A, peneliti mengumpulkan data dari instrumen tes melalui nilai hasil belajar pretest dan posttest pada tabel dibawah ini.

Tabel Nilai Hasil Pretest Siswa Kelas VIII-A MTs Annur Kota Sorong 1

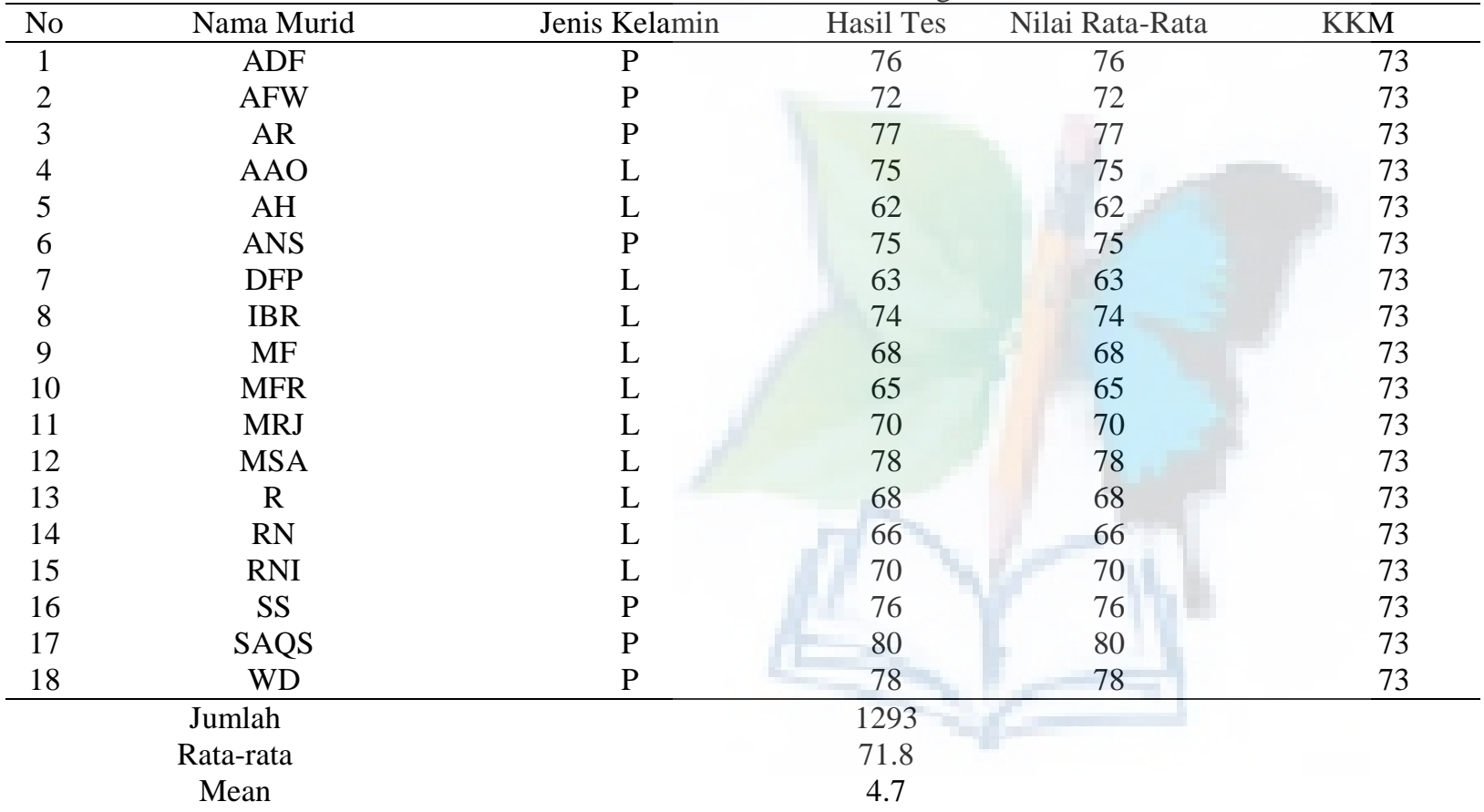


Simpangan Baku 5.5

Tabel Frekuensi Nilai Hasil Pretest 3.1.2.

\begin{tabular}{cccc}
\hline No & Nilai & Frekuensi & Persentase $(\%)$ \\
\hline 1 & $80-100$ & 1 & 2,4 \\
2 & $73-79$ & 8 & 44,4 \\
3 & $63-72$ & 8 & 44,4 \\
4 & $33-62$ & 1 & 2,4 \\
5 & $33-0$ & 0 & 0 \\
\hline & & 18 & 100 \\
\hline
\end{tabular}

a. Nilai Rata-rata $=71,8$

b. Nilai Mean $=4,7$

c. Simpangan Baku $=5,5$

d. Nilai Tertinggi $=80$

e. $\quad$ Nilai Terendah $=62$

Berdasarkan tabel 4.1.2 bahwa nilai tes dapat diketahui dari 18 siswa yang mendapatkan nilai di atas KKM yakni 73 hanya 9 siswa atau sebesar $50 \%$, sedangkan ada 9 atau 50\% siswa yang nilainya dibawah KKM

Tabel 2. Nilai Hasil Posttest Siswa Kelas VIII-A MTs Annur Kota Sorong

\begin{tabular}{cccccc}
\hline No & Nama Murid & Jenis Kelamin & Nilai Tes & Nilai Rata-Rata & KMM \\
\hline 1 & ADF & P & 90 & 90 & 73 \\
2 & AFW & P & 94 & 94 & 73 \\
3 & AR & P & 94 & 94 & 73 \\
4 & AAO & L & 86 & 86 & 73 \\
5 & AH & L & 80 & 80 & 73 \\
6 & ANS & P & 92 & 92 & 73 \\
7 & DFP & L & 84 & 84 & 73 \\
8 & IBR & L & 88 & 88 & 73 \\
9 & MF & L & 78 & 78 & 73 \\
10 & MFR & L & 76 & 76 & 73 \\
11 & MRJ & L & 78 & 78 & 73 \\
12 & MSA & L & 90 & 90 & 73 \\
13 & R & L & 84 & 84 & 73 \\
14 & RN & L & 75 & 75 & 73 \\
15 & RNI & L & 77 & 92 & 73 \\
16 & SS & P & 92 & 95 & 73 \\
17 & SAS & P & 95 & 90 & \\
18 & WD & & 90 & & \\
\hline \multicolumn{7}{c}{ Simpangan Baku } & & 1543 & & \\
\hline
\end{tabular}

Tabel Frekuensi Nilai Hasil Posttes.

\begin{tabular}{cccc}
\hline No & Nilai & Frekuensi & Persentase $(\%)$ \\
\hline 1 & $80-100$ & 13 & 72 \\
2 & $73-79$ & 5 & 28 \\
3 & $63-72$ & 0 & 0 \\
4 & $33-62$ & 0 & 0 \\
5 & $33-0$ & 0 & 0 \\
\hline
\end{tabular}

a. $\quad$ Nilai Rata-rata $=85,7$

b. Nilai Mean $=6$

c. Simpangan Baku $=6,9$

d. Nilai Tertinggi $=95$

e. $\quad$ Nilai Terendah $=75$ 
Berdasarkan tabel di atas diketahui bahwa siswa yang sudah memenuhi KKM yaitu $\geq 73$ terdapat 18 siswa (100\%). Hal tersebut dapat dilihat dari jumlah nilai siswa yang mendapatkan nilai 73 ke atas. Sedangkan yang belum mencapai KKM $\leq 73$ tidak ada.

Tabel Data Nilai Hasil Pretest dan Posttest 3

\begin{tabular}{|c|c|c|c|c|}
\hline No & $\begin{array}{l}\text { Nama } \\
\text { Murid }\end{array}$ & $\begin{array}{c}\text { Jenis } \\
\text { Kelamin }\end{array}$ & $\begin{array}{c}\text { Hasil } \\
\text { Pretest }\end{array}$ & $\begin{array}{l}\text { Hasil } \\
\text { Posttest }\end{array}$ \\
\hline 1 & ADF & $\mathrm{P}$ & 76 & 90 \\
\hline 2 & AFW & $\mathrm{P}$ & 72 & 94 \\
\hline 3 & AR & $\mathrm{P}$ & 77 & 94 \\
\hline 4 & $\mathrm{AAO}$ & $\mathrm{L}$ & 75 & 86 \\
\hline 5 & $\mathrm{AH}$ & $\mathrm{L}$ & 62 & 80 \\
\hline 6 & ANS & $\mathrm{P}$ & 75 & 92 \\
\hline 7 & DFP & $\mathrm{L}$ & 63 & 84 \\
\hline 8 & IBR & $\mathrm{L}$ & 74 & 88 \\
\hline 9 & $\mathrm{MF}$ & $\mathrm{L}$ & 68 & 78 \\
\hline 10 & MFR & $\mathrm{L}$ & 65 & 76 \\
\hline 11 & MRJ & $\mathrm{L}$ & 70 & 78 \\
\hline 12 & MSA & $\mathrm{L}$ & 78 & 90 \\
\hline 13 & $\mathrm{R}$ & $\mathrm{L}$ & 68 & 84 \\
\hline 14 & $\mathrm{RN}$ & $\mathrm{L}$ & 66 & 75 \\
\hline 15 & RNI & $\mathrm{L}$ & 70 & 77 \\
\hline 16 & SS & $\mathrm{P}$ & 76 & 92 \\
\hline 17 & SAQS & $\mathrm{P}$ & 80 & 95 \\
\hline 18 & WD & $\mathrm{P}$ & 78 & 90 \\
\hline \multicolumn{2}{|c|}{ Jumlah } & & 1293 & 1543 \\
\hline \multicolumn{2}{|c|}{ Rata-rata } & & 71.8 & 85.7 \\
\hline \multicolumn{2}{|c|}{ Mean } & & 4.7 & 6.0 \\
\hline \multicolumn{2}{|c|}{ Simpangan Baku } & & 5.5 & 6.9 \\
\hline
\end{tabular}

a. Uji Normalitas

Pengujian normalitas bertujuan untuk menyatakan apakah data hasil belajar biologi materi Struktur dan Fungsi Organ Tumbuhan untuk kelas VIII-A berdistribusi normal. Hipotesis untuk uji normalitas adalah sebagai berikut: Kriteria pengujian normalitas dengan hasil olahan IBM SPSS versi 20, yaitu jika sign $>\alpha$ maka data berdistribusi normal dan jika sign $<\alpha$ maka data tidak berdistribusi normal, dengan taraf signifikansi $\alpha=0,05$.

Tabel Distribusi Normalitas

One-Sample Kolmogorov-Smirnov Test

\begin{tabular}{|ll|r|}
\hline & & $\begin{array}{r}\text { Unstandardize } \\
\text { d Residual }\end{array}$ \\
\hline $\mathrm{N}$ & Mean & 18 \\
Normal & Std. & $0 \mathrm{E}-7$ \\
Parameters & Deviation & 4.25324102 \\
Most Extreme & Absolute & .104 \\
Differences & Positive & .104 \\
\multicolumn{1}{|c|}{ Kolmogorov-Smirnov Z } & -.072 \\
Asymp. Sig. (2-tailed) & .443 \\
\end{tabular}

a. Test distribution is Normal.

b. Calculated from data.

Berdasarkan hasil analisis KolmogorovSmirnov Test data untuk kelas eksperimen VIII-A dengan menggunakan model pembelajaran SQ4R (Survey, Question, Read, Reflect, Ricite, and
Review), diperoleh nilai signifikansi 0,989 untuk $\alpha=$ 0,05 , hal ini menunjukkan sign $>\alpha$. Ini berarti bahwa data hasil belajar siswa pada mata pelajaran biologi kelas eksperimen VIII-A dengan menggunakan metode SQ4R (Survey, Question, Read, Reflect, Ricite, and Review) terdistribusi normal.

Uji hipotesis ini bertujuan untuk mengetahui pengaruh hasil belajar Biologi struktur dan fungsi organ di kelas eksperimen. Dalam uji hipotesis ini menggunakan Uji Paired Sample Test.

Uji Paired Sample Test analisis menggunakan program SPSS 20 dengan hipotesis seperti diatas, dengan kriteria diterima Ha jika Sig. (2-tailed) kurang dari 0,05

Berdasarkan tabel Uji T di Lampiran Paired Sample Test diketahui nilai Sig.(2-tailed) adalah sebesar $0,000<0,05$, maka $\mathrm{HO}$ ditolak dan $\mathrm{Ha}$ diterima. Sehingga dapat disimpulkan bahwa ada pengaruh rata-rata nilai hasil belajar Pretest dan Posttest yang artinya ada pengaruh penggunaan model pembelajaran SQ4R terhadap hasil belajar pada materi struktur dan fungsi organ tumbuhan pada siswa kelas VIII-A MTs Annur Kota Sorong.

Berdasarkan tabel 1 dan 2 hasil penilaian pretest sebelum penerapan mode pembelajaran SQ4R dapat diketahui bahwa nilai tes dari 18 siswa yang mendapatkan nilai KKM yakni $\geq 73$ hanya 9 siswa atau sebesar $50 \%$, sedangkan ada 9 atau 50\% siswa yang nilainya dibawah KKM dengan nilai rata-rata = 71,8, sedangkan Berdasarkan tabel 4.1.3 dan 4.1.4. 
diketahui bahwa siswa yang sudah memenuhi KKM yaitu $\geq 73$ terdapat 18 siswa $(100 \%)$. Hal tersebut dapat dilihat dari jumlah nilai siswa yang mendapatkan nilai 73 ke atas, sedangkan yang belum mencapai $\mathrm{KKM} \leq 73$ tidak ada dengan nilai rata-rata hasil penilaian posttest $=85,7$. Hasil Belajar memiliki hasil yang serupa dengan penelitian lain seperti dibawah ini.

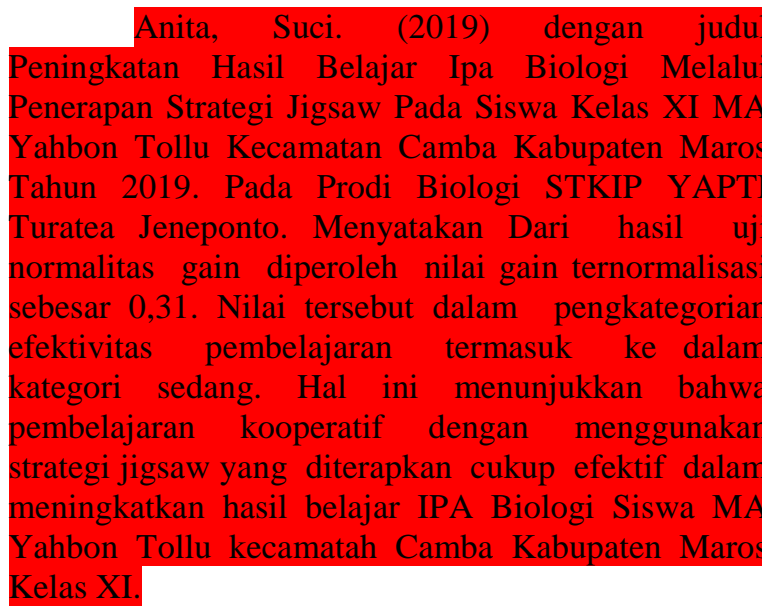

\section{Kesimpulan}

Dari hasil penelitian menunjukkan bahwa pengaruh penggunaan model pembelajaran SQ4R pada materi struktur dan organ tumbuhanterhadap hasil belajar biologi siswa kelas VIII-A MTs Annur Kota Sorong, dapat ditarik kesimpulan yaitu Penerapan Model pembelajaran SQ4R dengan menggunakan metode Talking Stick meningkatkan hasil belajar biologi siswa kelas VIII-AMTs Annur Kota Sorong khususnya di materi struktur dan fungsi organ pada tumbuhan dengan persentase ketuntasan belajar siswa pada pretest sebesar 50\% dengan kriteria belum tuntas dan mengalami peningkatan pada posttest dengan persentase ketuntasan belajar siswa sebesar $100 \%$ dengan kriteria semua siswa tuntas.

\section{Daftar Pustaka}

1. Akbar, Sa'dun dan Hadi Sriwiyana. 2010. Pengembangan Kurikulum dan Pembelajaran Ilmu Pengetahuan Sosial (IPS). Yogyakarta: Cipta Media Aksara.

2. Arikunto, Suharsimi. (2013). Prosedur Penelitian, Suatu Pendekatan Praktik. Jakarta: Rineka Cipta.

3. Anita, Suci (2019). Bioleaning Journal Peningkatan Hasil Belajar Ipa Biologi Melalui Penerapan Strategi Jigsaw Pada Siswa Kelas XI MA Yahbon Tollu Kecamatan Camba Kabupaten Maros Tahun 2019 Prodi Biologi STKIP YAPTI Turatea Jeneponto

4. Hong-Nam, Kay; Alexandra G. Leavell; \& Sheila Maher. (2014). The Relationships among Reported Strategy Use, Metacognitive Awareness, and Reading Achievement of High School Students. Reading Psychology. 35(8): 762790.
5. Joyce, Bruce. Dkk. 2009. Models of Teaching Model-model Pengajaran. Yogyakarta: Pustaka Pelajar.

6. Kunandar. (2014). Penilaian Autentik. Jakarta: Raja Grafindo Persada

7. Nurhadi. 2016. Strategi Meningkatkan Daya Baca. Jakarta: Bumi Aksara.

8. Peraturan Menteri Pendidikan dan Kebudayaan Republik Indonesia, Nomor 103 Tahun (2014) tentang Pembelajaran Pendidikan Dasar dan Pendidikan Menengah.

9. RC, Achmad Rifa'i dan Catharina Tri Anni. 2011. Psikologi Pendidikan. Semarang: Unnes Press.

10. Rustaman, Nuryani dkk. 2005. Strategi Belajar Mengajar Biologi. Malang: UM PRESS.

11. Sanjaya, Wina. 2006. Strategi Pembelajaran Berorientasi Standar Proses Pendidikan. Jakarta: Kencana Prenada Media Group

12. Shoimin, Aris. 2014. 68 Model Pembelajaran Inovatif dalam Kurikulum 2013. Yogyakarta: Ar Rus Media.

13. Slameto. 2010. Belajar Dan Faktor-Faktor Yang Mempengaruhinya (edisi revisi). Jakarta: Rineka Cipta

14. Sudjana, Nana. 2005. Dasar-Dasar Proses Belajar Mengajar. Bandung: Sinar Baru Algesindo

15. Sugiyono. 2007 dan 2012. Metode Penelitian Pendidikan Pendekatan Kuantitatif, Kualitatif, dan $R \& D$. Jakarta: Alfabeta

16. Sukardi. 2003. Metodologi Penelitian Pendidikan Kompetensi dan Prakteknya. Jakarta: Bumi Aksara.

17. Suprijono, Agus. 2009. Cooperative Learning. Yogyakarta: Pustaka Belajar.

18. Syaodih Sukmadinata, Nana. 2009. Landasan Psikologi Proses Pendidikan. Bandung: PT. Remaja Rosdakarya

19. Trianto. 2014. Mendesain Model Pembelajaran Inovatif, Progresif, dan Kontekstual. Jakarta: Kencana Prenada Grup.

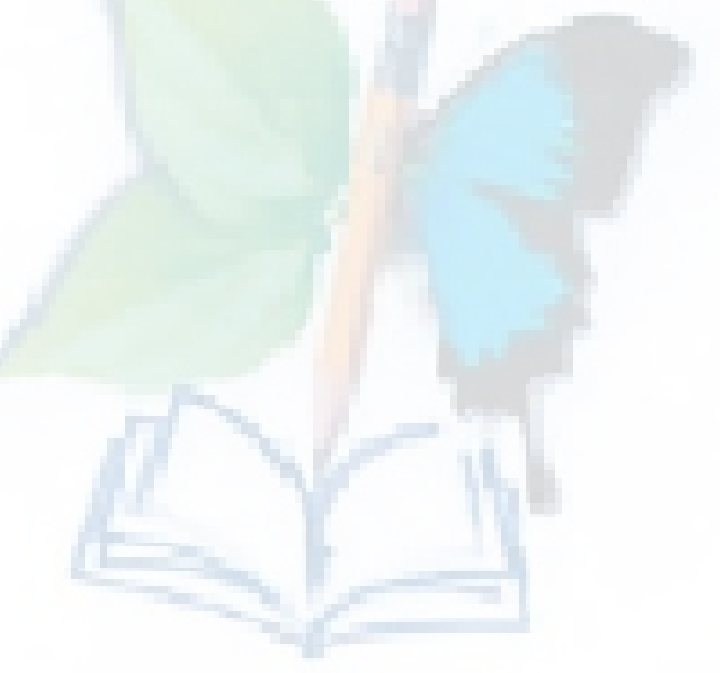

